\title{
Perancangan Knowledge Sharing Systems Database Di Program Studi Teknik Informatika
}

\author{
Caca E. Supriana ${ }^{1, *}$ \\ 1 Teknik Informatika; Universitas Pasundan; Jalan Setiabudi 193 Bandung, Telp/fax.022- \\ 2021440, 2019433; e-mail: caca.e.supriana@unpas.ac.id \\ * Korespondensi: e-mail: caca.e.supriana@unpas.ac.id
}

Diterima: 26 Agustus 2021; Review: 09 September 2021; Disetujui: 16 September 2021

Cara sitasi: Supriana CE. 2021. Perancangan Knowledge Sharing System Database Di Program Studi Teknik Informatika. Bina Insani ICT Journal. Vol. 8 (2): 123-135.

\begin{abstract}
Abstrak: Program Studi Teknik Informatika sebagai sebuah organisasi bergantung pada pengambil keputusan untuk mendukung visi dan misi organisasi berdasarkan masukan dari beberapa domain pengetahuan. Kompleksitas domain pengetahuan yang mendasari pengambilan keputusan semakin meningkat dengan perkembangan teknologi informasi dan komputer serta persaingan dengan organisasi lain. Knowledge Sharing Systems (KSS) dirancang untuk membantu pengguna berbagi pengetahuan. Perancangan proses yang saling terkait untuk mengelola informasi menjadi pengetahuan dan menyebarkannya kepada pemangku kepentingan di Program Studi. Informasi yang dikelola bersumber dari data dalam sistem informasi yang harus disimpan dan dikelola dengan efektif dan efisien. Pemanfaatan basis data sebagai kelanjutan perancangan sistem informasi untuk mendukung penyebaran atau pembagian pengetahuan akan mendukung kebutuhan tersebut, perancangan ini disebut Knowledge Sharing Systems Database (KSSDB). Penelitian ini akan menganalisis bagaimana pengetahuan diambil, disimpan serta dibagi kepada setiap pemangku kepentingan sebagai aset berharga di lingkungan program studi, sebagai acuan pengambilan keputusan serta pendukung pencapaian misi dan misi program studi dengan dukungan perancangan basis data. Hasil penelitian ini adalah perancangan model KSSDB, dengan menggunakan metode siklus hidup basis data yang dimulai dari analisis sistem informasi, perancangan model basis data sampai dengan pembangunan basis data fisik untuk meningkatkan pengetahuan dengan studi kasus Program Studi Teknik Informatika Universitas Pasundan. KSSDB akan membantu pengelolaan data untuk mendukung penyebaran pengetahuan, baik dalam Program Studi atau antar Program Studi di Fakultas Teknik dalam mendukung pelaksanaan Tri Dharma Perguruan Tinggi dan meningkatkan kualitas pengetahuan berbagai pihak yang terlibat.
\end{abstract}

Kata kunci: Knowledge Sharing Systems Database, manajemen pengetahuan, Prodi Teknik Informatika

Abstract: The Informatics Engineering Study Program as an organization relies on decision makers to support the organization's vision and mission based on input from several knowledge domains. The complexity of the knowledge domain that underlies decision making is increasing with the development of information and computer technology and competition with other organizations. Knowledge Sharing Systems (KSS) are designed to help users share knowledge. Design of interrelated processes to manage information into knowledge and disseminate it to stakeholders in the Study Program. The managed information from data in the information system which must be stored and managed effectively and efficiently. Utilization of databases as a continuation of the design of information systems to sharing of knowledge will support these needs, this design is Knowledge Sharing Systems Database (KSSDB). This study will analyze how knowledge is taken, stored and shared with each stakeholder as a valuable asset in the study program environment, as a reference for decision making and supporting the achievement of the study program's mission and mission with the support of database design. 
The result of this research is the design of the KSSDB model, using the database life cycle method starting from information system analysis, database model design to the construction of a physical database to increase knowledge with a case study of the Informatics Engineering Study Program, Pasundan University. KSSDB will assist data management to support the dissemination of knowledge, both within Study Programs or between Study Programs at the Faculty of Engineering in supporting the implementation of the Tri Dharma of Higher Education and improving the quality of knowledge of the various parties involved.

Keywords: knowledge management, Knowledge Sharing Systems Database, Informatics Engineering Study Program

\section{Pendahuluan}

Program Studi Teknik Informatika sebagai sebuah organisasi perlu melaksanakan pengambilan keputusan yang tepat, mengacu pada pengelolaan pengetahuan yang dimiliki dengan teratur dan terencana untuk mencapai visi dan misinya. Kegiatan atau proses bisnis dalam Program studi yang mengacu pada Tri Dharma Perguruan Tinggi untuk melaksanakan Pengajaran, Penelitian dan Pengabdian Masyarakat sangat memerlukan pengambilan keputusan yang didukung oleh sumber pengetahuan yang baik. Faktor pengelolaan pengetahuan menjadi salah satu faktor penting dalam peningkatan kualitas Program Studi. Kuantitas dan kualitas pengetahuan yang meningkat dengan cepat memerlukan pengelolaan yang baik memanfaatkan manajemen pengetahuan yang dirancang dengan baik, didukung organisasi, didukung, dibagikan dan dimanfaatkan oleh pihak-pihak yang berkepentingan serta didukung dengan pemanfaatan teknologi informasi yang maksimal. Sebagian besar aktivitas manajemen pengetahuan merupakan kombinasi dari proses bisnis dan teknologi informasi.

Sistem informasi yang telah dirancang memerlukan teknologi untuk mengelola data, memproses menjadi informasi dan dikelola serta dibagikan sebagai pengetahuan maka diperlukan DBMS (Database Management Systems) sebagai sarana penyimpanan pengetahuan tersebut. Dalam hal teknologi, sebagian besar aktivitas manajemen pengetahuan saat ini bergantung pada database dan internet, disimpan dalam database baik dalam bentuk tabel sederhana atau teks semi-terstruktur. Mendapatkan kembali pengetahuan dengan cara terbaik dan teraman, harus menangkapnya dalam sistem yang memungkinkan penggunaan query yang selektif dan cepat dalam lingkungan yang terkontrol. DBMS adalah alat yang efektif dan baik serta mendukung untuk manajemen pengetahuan secara umum dan Knowledge Sharing System secara khusus. Pengetahuan dipecah menjadi fakta atribut terkecil yang dapat disimpan dalam database relasional standar dan diproses dengan sangat efisien, menyediakan query untuk mencari informasi dari basis pengetahuan, inferensi efisien dari pengetahuan baru dan terjemahan ke dalam dan keluar dalam bahasa yang dipahami pengguna. Pembagian pengetahuan juga diproses dengan penjelasan bahasa yang lengkap dari mana jawaban itu berasal.

\section{Metode Penelitian}

Metodologi dari penelitian ini adalah sebagai berikut: 1) pengumpulan data, data yang relevan secara teoritis atau yang didapatkan dari organisasi tempat penelitian untuk menunjang tahap analisis serta perancangan. Pengumpulan data yang dilakukan adalah melalui studi literatur mengenai Knowledge Sharing System, observasi dan wawancara, 2) analisis proses dan data yang digunakan dalam organisasi, serta analisis dalam bentuk model sistem informasi, 3) analisis data dan informasi yang ada dalam sistem informasi dan mengidentifikasi pengetahuan tacit dan eksplisit yang dikelola, dan 4) perancangan basis data Knowledge Sharing System dan evaluasinya, penelitian diakhiri dengan pengambilan kesimpulan. Berikut adalah penjelasan dari metodologi penelitian yang dilaksanakan dalam penelitian ini:

Melakukan studi literatur terhadap referensi yang berkaitan dengan manajemen pengetahuan, sistem informasi dan Tri Dharma Perguruan Tinggi serta penelitian-penelitian yang berkaitan, melakukan observasi lapangan di Program Studi Teknik Informatika Universitas Pasundan serta melakukan wawancara untuk mengetahui pelaksanaan manajemen pengetahuan, pemanfaatan sistem informasi serta identifikasi pengetahuan tacit dan eksplicit yang ada dalam pelaksanaan Tri Dharma.

Analisis proses dan data yaitu melakukan identifikasi terhadap data yang membentuk informasi dalam pelaksanaan berbagai kegiatan yang mendukung Tri Dharma Perguruan Tinggi 
di Program Studi Teknik Informatika Universitas Pasundan. Identifikasi proses yang terjadi dalam pengelolaan data tersebut dan bagaimana data disebarkan kepada pihak-pihak yang berkepentingan.

Analisis sistem informasi dalam manajemen pengetahuan, khususnya penyebaran atau pembagian pengetahuan dalam pelaksanaan Tri Dharma. Identifikasi pihak-pihak yang terlibat sebagai entitas eksternal, proses serta dekomposisi proses yang mengalirkan data, membuat struktur proses lengkap, membentuk informasi yang mengelola data masuk dan mengolah produk informasi dari sistem informasi yang akan mendukung pengetahuan dan membagikannya.

Perancangan basis data yang mengacu pada data yang dikelola dan tersimpan dalam sistem informasi Knowledge Sharing System, mulai data atribut pembentuk informasi, membentuk entitas, relasi antar entitas yang dilanjutkan menjadi model basis data. Pemetaan dari model basis data ke basis data logik untuk memeriksa kelengkapan atribut pendukung informasi, melakukan proses normalisasi jika diperlukan dan sebagai hasil akhir adalah basis data fisik dengan menggunakan standar aplikasi basis data MySQL/MariaDB.

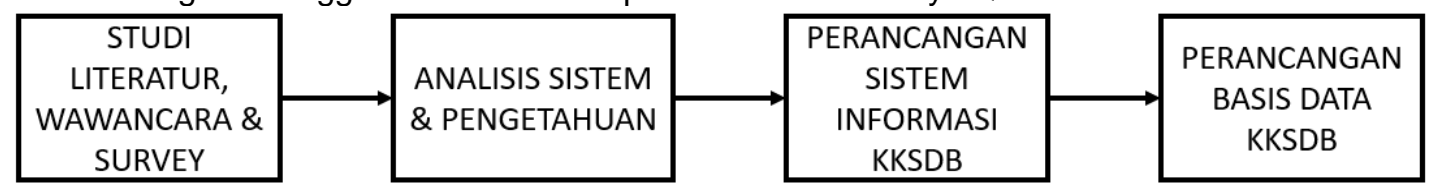

Sumber: Hasil Penelitian (2021)

Gambar 1. Metodologi Penelitian

\section{Hasil dan Pembahasan}

Pengetahuan sangat berbeda dari data dan informasi, meskipun tiga istilah ini kadangkadang digunakan secara bergantian, tetapi sangat berbeda sifatnya. Data terdiri dari fakta, pengamatan, atau persepsi, sehingga data mewakili angka mentah atau pernyataan dan karena itu dapat tanpa konteks, makna, atau maksud. Pengetahuan telah dibedakan dari data dan informasi dalam dua cara yang berbeda. Pandangan yang lebih sederhana menganggap pengetahuan sebagai tingkat tertinggi dalam hierarki dengan informasi di tingkat menengah dan data di tingkat terendah. Menurut pandangan ini, pengetahuan mengacu pada informasi yang memungkinkan tindakan dan keputusan atau informasi dengan kepentingan. Pengetahuan pada dasarnya serupa dengan informasi dan data, meskipun itu adalah yang terkaya dan terdalam dari ketiganya, dan yang paling berharga [5].

Informasi adalah data dalam sebuah konteks sementara pengetahuan adalah informasi yang memfasilitasi tindakan atau pengambilan keputusan, misalnya, individu yang merupakan pakar domain dalam suatu organisasi. Meskipun pandangan sederhana tentang pengetahuan ini mungkin tidak sepenuhnya akurat, itu tidak sepenuhnya menjelaskan karakteristik pengetahuan. Definisi pengetahuan adalah sebagai keyakinan yang dibenarkan tentang hubungan antara konsep yang relevan dengan bidang tertentu.

Pengetahuan yang menjadi sumber penelitian akan mencakup pengetahuan eksplisit dan pengetahuan tacit. Pengetahuan eksplisit biasanya mengacu pada pengetahuan yang telah diungkapkan ke dalam kata dan angka. Pengetahuan semacam itu dapat dibagi secara formal dan sistematis dalam bentuk data, spesifikasi, manual, gambar, audio dan kaset video, program komputer, paten, dan sejenisnya. Pengetahuan tacit mencakup wawasan, intuisi, dan firasat. Sulit untuk mengungkapkan dan menjelaskannya karena sehingga sulit untuk dibagikan. Pengetahuan tacit lebih cenderung bersifat pribadi dan berdasarkan pada pengalaman dan aktivitas individu [12].

\section{Sistem Informasi}

Sistem informasi adalah pendukung penting proses bisnis organisasi. Sistem informasi memfasilitasi komunikasi dan koordinasi di antara area fungsional yang berbeda, dan memungkinkan pertukaran, akses data secara mudah antar proses. Secara khusus, sistem informasi memainkan peran penting dalam tiga bidang yaitu menjalankan proses, menangkap dan menyimpan data proses dan memantau kinerja proses. Sistem informasi membantu organisasi melaksanakan proses secara efisien dan efektif. Sistem informasi biasanya tertanam ke dalam proses dan memainkan peran penting dalam menjalankan proses. Sistem informasi dan proses biasanya saling terkait, jika sistem informasi tidak berfungsi, proses tidak dapat 
dijalankan. Sistem informasi membantu menjalankan proses dengan memberi tahu orang-orang kapan saatnya menyelesaikan tugas, dengan menyediakan data yang diperlukan untuk menyelesaikan tugas dan menyediakan sarana untuk menyelesaikan tugas. Sistem informasi menangkap dan menyimpan data yang berhubungan dengan proses bisnis, biasanya disebut sebagai data proses atau data transaksi. Sistem informasi adalah membantu memantau keadaan berbagai proses bisnis, menunjukkan seberapa baik suatu proses dieksekusi. Sistem informasi melakukan peran ini dengan mengevaluasi informasi tentang suatu proses [9].

\section{Knowledge Management}

Manajemen pengetahuan (KM) adalah perencanaan, pengorganisasian, memotivasi, dan mengendalikan orang, proses dan sistem dalam organisasi untuk memastikan bahwa aset terkait pengetahuannya ditingkatkan dan digunakan secara efektif. Aset yang berhubungan dengan pengetahuan mencakup pengetahuan dalam bentuk dokumen cetak seperti paten dan manual, pengetahuan yang disimpan dalam repositori elektronik seperti database "praktik terbaik", pengetahuan karyawan tentang cara terbaik untuk melakukan pekerjaan mereka, pengetahuan yang dimiliki oleh tim yang telah mengerjakan masalah dan pengetahuan terfokus yang tertanam dalam produk, proses, dan hubungan organisasi. Proses-proses KM melibatkan penguasaan pengetahuan, penciptaan, penyempurnaan, penyimpanan, transfer, berbagi, dan pemanfaatan. KM mendapat data yang diolah oleh sebuah organisasi termasuk informasi hasil proses dan produk sebuah sistem informasi, mengolahnya menjadi pengetahuan untuk mendukung sistem informasi tersebut atau mendukung pemanfaatan informasi.

Fungsi KM dalam organisasi mengoperasikan proses ini, mengembangkan metodologi dan sistem untuk mendukungnya, dan memotivasi orang untuk berpartisipasi di dalamnya. Tujuan KM adalah meningkatkan dan meningkatkan aset pengetahuan organisasi untuk mewujudkan praktik pengetahuan yang lebih baik, meningkatkan perilaku organisasi, keputusan yang lebih baik, dan meningkatkan kinerja organisasi. Walaupun individu secara pribadi dapat melakukan masing-masing proses KM, KM sebagian besar merupakan aktivitas organisasi yang berfokus pada apa yang dapat dilakukan manajer untuk memungkinkan tujuan KM tercapai, bagaimana mereka dapat memotivasi individu untuk berpartisipasi dalam mencapainya dan bagaimana mereka dapat menciptakan proses sosial yang akan memfasilitasi kesuksesan KM [5][7].

\section{Knowledge Sharing Systems}

Kemampuan organisasi dan individu di dalamnya untuk saling berbagi pengetahuan, khususnya pengetahuan organisasi, diidentifikasi sebagai salah satu faktor yang berkontribusi terhadap daya saing organisasi. Berbagi pengetahuan membantu individu dan organisasi akan membangun pengetahuan. Hal ini karena memungkinkan mereka untuk berdiskusi dan berunding tentang topik-topik tertentu yang dapat mendorong generasi pengetahuan baru. Terlepas dari pentingnya berbagi pengetahuan dalam membangun pengetahuan organisasi perusahaan, yang pada akhirnya meningkatkan daya saing perusahaan, terdapat alasan bahwa karyawan tidak mau membagikan pengetahuan mereka secara sukarela. Ada lima alasan mengapa karyawan atau pelaku sistem enggan untuk berbagi pengetahuan, yaitu (i) ketakutan akan penurunan nilai pribadi, (ii) biaya yang terlibat, (iii) ketidakpastian tentang bagaimana penerima akan menggunakan pengetahuan yang dibagikan, (iv) menerima dan menghormati kekuatan hierarkis dan formal yang kuat, dan (v) konsekuensi negatif aktual dari berbagi pengetahuan dengan bawahan [8][11]. Sistem berbagi pengetahuan dapat digambarkan sebagai sistem yang memungkinkan anggota organisasi untuk memperoleh pengetahuan dan eksplisit dari satu sama lain. Tujuan utama dari sistem ini adalah untuk mempromosikan berbagi pengetahuan untuk digunakan kembali oleh anggota lain dari organisasi yang sama dan penyebaran inovasi, teknologi, dan manajemen strategis. Dalam sistem berbagi pengetahuan, pemilik pengetahuan akan (1) ingin berbagi pengetahuan mereka dengan grup yang terkendali dan tepercaya, (2) memutuskan kapan harus berbagi dan ketentuan untuk berbagi, dan (3) mencari pertukaran yang adil, atau keuntungan, untuk berbagi pengetahuan [5][10].

\section{Sumber Pengetahuan Di Prodi Teknik Informatika}

Program studi yang bernaung dibawah perguruan tinggi melayani kepentingan nasional yaitu melaksanakan penelitian (khususnya penelitian publik) memainkan peran penting dalam 
pembangunan ekonomi regional dan nasional. Penemuan yang dibuat atau pengetahuan baru dalam penelitian perguruan tinggi akan bermanfaat dan memajukan budaya di wilayah dan negara. Kurikulum yang digunakan di program studi merupakan keseluruhan rencana dan pengaturan mengenai capaian pembelajaran lulusan, bahan kajian, proses dan penilaian pembelajaran yang digunakan sebagai pedoman penyelenggaraan program studi pada sistem pendidikan khususnya pendidikan tinggi (Permen Dikbud 49 Thn 2014). Dalam penyusunan kurikulum perguruan tinggi khususnya kurikulum di prodi Teknik Informatika, khususnya yang berkaitan dengan penelitian dimulai dengan pembuatan struktur kurikulum yang sesuai standar nasional dan internasional (Computer Science Curricula (CSC) 2013, Curriculum Guidelines for Undergraduate Degree Programs in Information Systems Association for Computing Machinery (ACM) dan Association for Information Systems (AIS) 2010) serta dilanjutkan dengan penentuan capaian pembelajaran lulusan [1].

Pembagian kelompok keilmuan di Prodi Teknik Informatika mengacu pada kelompok keilmuan yang menjadi sumber penyusunan kurikulum. Kelompok keilmuan ini terbagi menjadi 4 (empat) yaitu (1) Keilmuan Rekayasa Perangkat Lunak dengan konsentrasi di bidang algoritma, pemrograman, basis data dan rekayasa perangkat lunak, (2) Keilmuan Sistem Informasi dengan konsentrasi di bidang manajemen, manajemen proyek, interaksi manusia komputer dan sistem informasi, (3) Keilmuan Teknologi Informasi dengan konsentrasi di bidang perangkat keras, jaringan komputer, sistem operasi, keamanan jaringan dan teknologi informasi serta (4) Keilmuan Multimedia dengan konsentrasi di bidang desain perangkat lunak dan multimedia. Pengelompokan ini cukup fleksibel khususnya dalam hal penelitian sebagai pengembangan pengetahuan, satu kelompok keilmuan dapat bekerja sama dengan kelompok keilmuan lainnya. Landasan penelitian dari pihak perguruan tinggi disesuaikan dengan visi dan misi perguruan tinggi tersebut yang disesuaikan dengan fakultas serta dilaksanakan di lingkungan program studi atau antar program studi dengan otonomi penelitian sesuai dengan bidang keilmuan masing-masing [3].

\section{Basis Data}

Manajemen data, khususnya sistem informasi yang efisien biasanya membutuhkan penggunaan sistem basis data. Basis data adalah struktur komputer bersama yang terintegrasi yang menyimpan kumpulan data pengguna akhir, yaitu fakta mentah yang berguna bagi pengguna akhir. Metadata, atau data tentang data, di mana data pengguna akhir diintegrasikan dan dikelola. Metadata memberikan deskripsi karakteristik data dan kumpulan hubungan yang menghubungkan data yang ditemukan dalam database, misalnya komponen metadata menyimpan informasi seperti nama setiap elemen data, jenis nilai (numerik, tanggal, atau teks) yang disimpan pada setiap elemen data, apakah elemen data tersebut boleh dikosongkan atau tidak, dan seterusnya. Metadata memberikan informasi yang melengkapi dan memperluas nilai dan penggunaan data. Singkatnya, metadata menyajikan gambaran yang lebih lengkap tentang data dalam database. Sistem manajemen basis data (DBMS) adalah kumpulan program yang mengelola struktur basis data dan mengontrol akses ke data yang disimpan dalam basis data. Basis data menyerupai lemari arsip elektronik yang sangat terorganisir dengan baik di mana perangkat lunak yang kuat, yang dikenal sebagai sistem manajemen database, membantu mengelola isi kabinet [2][6].

\section{Proses Berbagi Pengetahuan Di Program Studi}

Perancangan kegiatan di lingkungan Perguruan Tinggi, baik tingkat Fakultas atau tingkat Program Studi terhadap pihak yang berkepentingan seperti dosen sangat penting dalam berbagi pengetahuan. Perancangan kegiatan seperti dalam pengajaran, penelitian dan pengabdian masyarakat dapat memiliki dampak terhadap motivasi dosen untuk berbagi pengetahuan, dengan memanfaatkan berbagai media khususnya yang memiliki dukungan teknologi informasi. Berbagi pengetahuan dalam kelompok atau organisasi selalu berakar pada perilaku orang-orang yang terlibat, dalam hal ini adalah dosen dan alasan pendukungnya. 


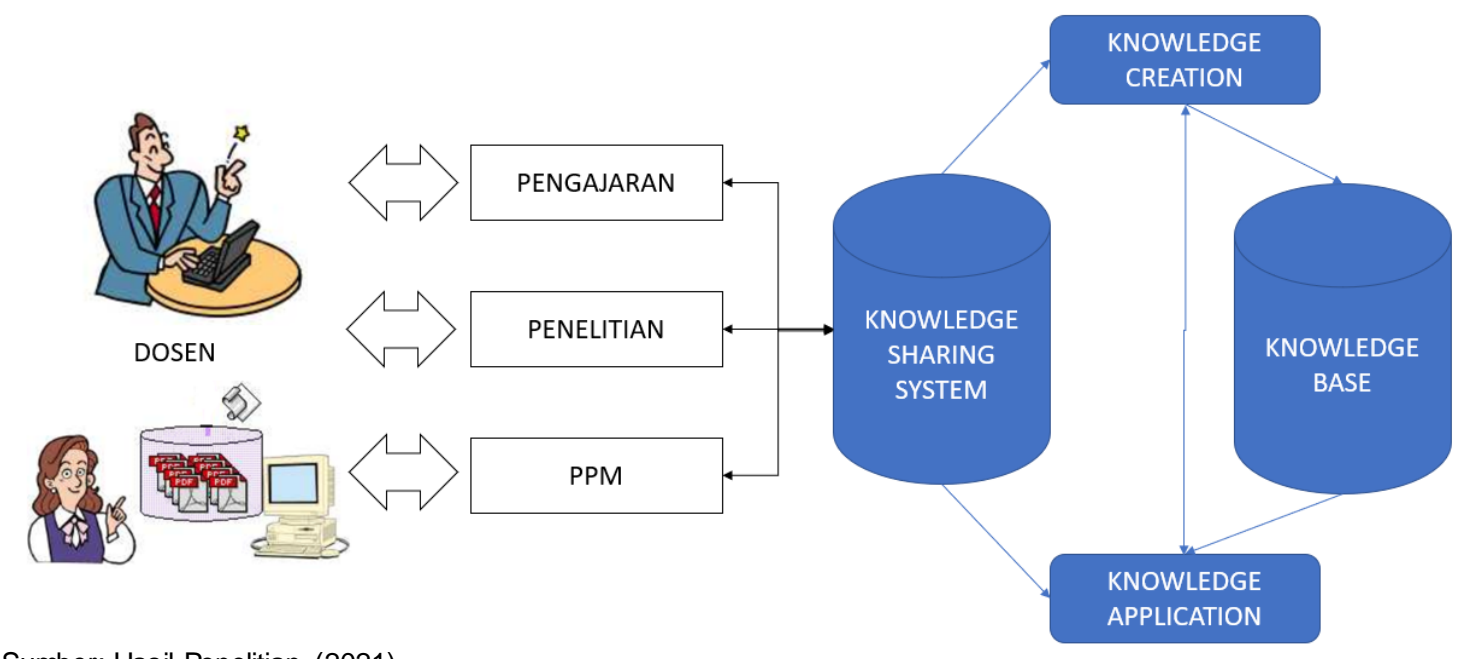

Sumber: Hasil Penelitian (2021)

Gambar 2. Workflow Knowledge Sharing System

Perancangan kegiatan berbagi pengetahuan akan memperhatikan beberapa aspek berikut: a) Otonomi: otonomi berkaitan dengan kesempatan dari pelaksana tugas, dosen akan menentukan bagaimana dan kapan dalam melaksanakan tugas atau kegiatan yang telah disiapkan. Dosen diberikan kebebasan, indepedensi dan kebijaksanaan sesuai penilaiannya untuk melaksanakan penjadwalan pekerjaan dan cara untuk menyelesaikan tanggung jawabnya. Otonomi akan berelasi dengan produktivitas yang baik serta memberikan ruang bebas untuk belajar dan berkembang, b) Identifikasi Tugas: memberikan tanggung jawab penuh pada pelaksana untuk melaksanakan tugas mulai dari awal sampai dengan selesai. Tugas yang dapat dengan mudah diidentifikasi oleh dosen, sesuai dengan keilmuan dosen tersebut, sesuai dengan minat dan kemampuannya. Identifikasi tugas yang baik akan mendukung motivasi dosen dalam menyelesaikan kegiatan atau pekerjaan, c) Umpan Balik: bagaimana dosen mendapat informasi langsung yang jelas mengenai unjuk kerja pelaksanaan kegiatan atau pekerjaan. Umpan balik yang diharapkan akan mendukung kompetensi dosen yang pada akhirnya akan meningkatkan motivasi dan unjuk kerja.

Ketiga aspek yang telah dibahas diatas adalah untuk mendukung dosen dalam berbagi pengetahuan, yang ditampung, dikelola dan dibagikan dalam organisasi. Berbagai aspek dalam perancangan pekerjaan akan membentuk motivasi dosen, secara umum motivasi dalam berbagi pengetahuan terbagi mejadi: 1) Motivasi Intrinsik: bagaimana seorang dosen dalam melaksanakan kegiatan pengajaran, penelitian dan pengabdian masyarakat, yang akan menghasilkan kreativitas, kualitas dan tingkat pembelajaran yang baik yang pada akhirnya akan mendukung berbagi pengetahuan, 2) Motivasi Proyeksi: bagaimana kegiatan yang dilaksanakan oleh dosen akan memperhatikan pemeliharaan dan peningkatan keilmuan di dalam organisasi dan kelompok sosial. Dosen akan merasa bertanggung jawab akan peningkatan keilmuan di tingkat Program Studi, berusaha untuk berbagi pengetahuan sesuai dengan rancangan kegiatan sehingga akan timbul perasaan memiliki nilai dan manfaat dalam kelompok, dan 3) Motivasi Eksternal: bagaimana dosen mendapat keuntungan dari berbagi pengetaguan dari dosen lainnya dalam menyelesaikan kegiatan, tugas dan tanggung jawab yang telah dirancang oleh organisasi.

\section{Perancangan Proses}

Perancangan proses dalam sistem informasi knowledge sharing mengacu pada analisis pengelolaan dan pembagian pengetahuan di Program Studi Teknik Informatika Universitas Pasundan: 1) belum tersedianya sistem informasi dan aplikasi basis data khusus mengelola dan membagikan pengetahuan, terutama pengetahuan tacit yang dimiliki oleh dosen pengajar dalam melaksanakan kegiatan pengajaran, penelitian dan pengabdian masyarakat, dan 2) mengintegrasikan perancangan basis data knowledge sharing ke sistem informasi terintegrasi milik Fakultas Teknik Universitas Pasundan dalam rangka manajemen pengetahuan, pendukung pengambilan keputusan dan penilaian. 
Proses-proses yang dirancancang dalam sistem informasi knowledge sharing di Program Studi Teknik Informatika Universitas Pasundan ini ditujukan untuk mendukung otonomi, identifikasi tugas dan umpan balik. Berikut adalah proses-proses utama dalam sistem informasi:

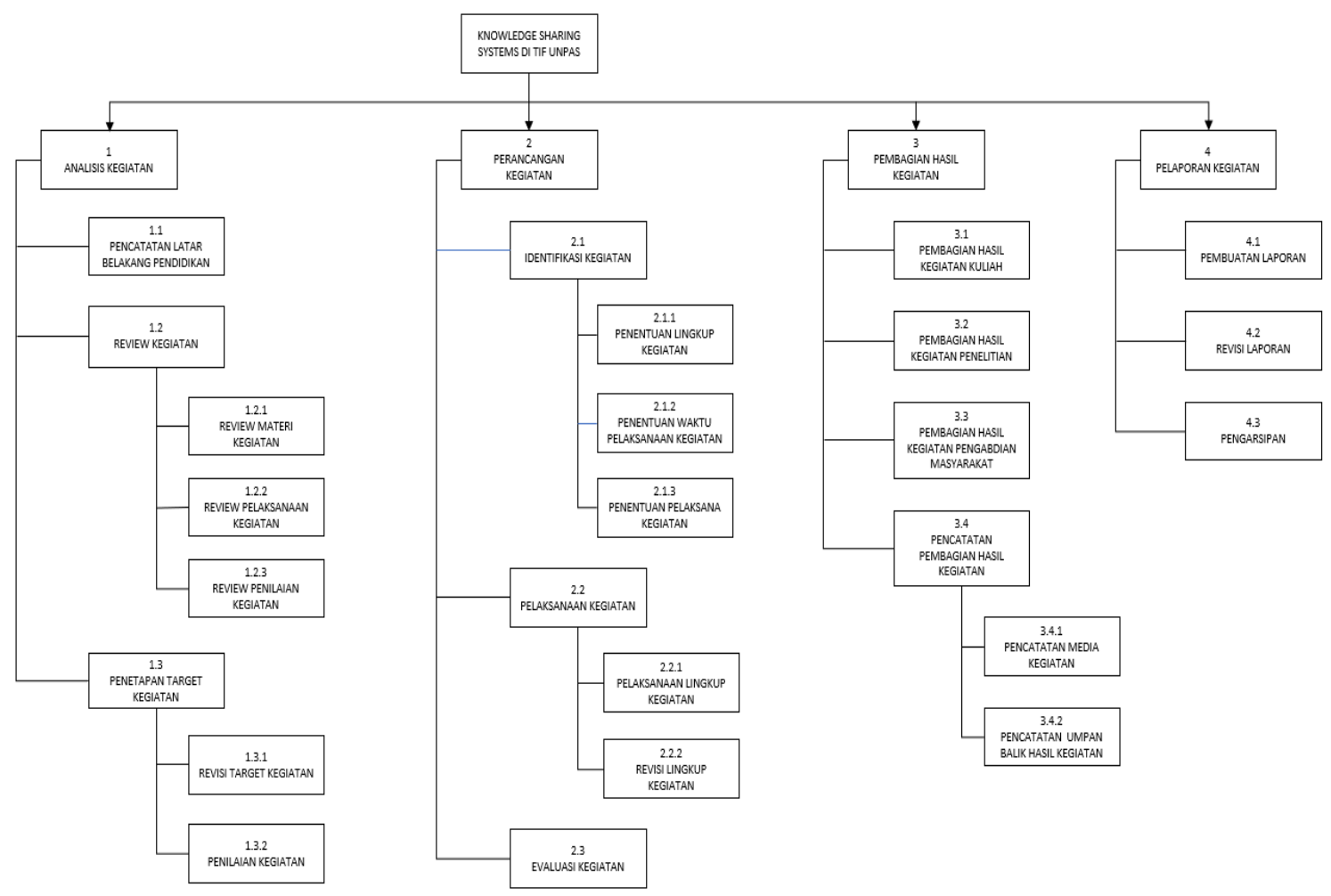

Sumber: Hasil Penelitian (2021)

Gambar 3. Struktur Proses Sistem Informasi Knowledge Sharing Systems

Adapun penjelasan dari gambar 3 adalah: 1) Analisis Kegiatan adalah proses yang melakukan pencatatan dan revisi hasil kegiatan keilmuan yang sebelumnya pernah dilaksanakan. Proses ini akan memastikan bahwa status kegiatan sebelumnya akan dilanjutkan dengan penetapan target untuk memastikan peningkatan keilmuan. Analisis kegiatan akan mendukung otonomi dan identifikasi tugas, 2) Perancangan Kegiatan adalah proses kelanjutan dari analisis kegiatan yang melakukan identifikasi kegiatan baru, melakukan pengawasan serta umpan balik untuk pelaksanaan kegiatan dan melaksanakan evaluasi kegiatan. Perancangan kegiatan memastikan kegiatan yang tepat untuk keilmuan serta minat dosen tertentu. Perancangan kegiatan akan mendukung identifikasi tugas dan umpan balik, 3) Pembagian Hasil Kegiatan proses yang akan membagikan hasil kegiatan pengajaran, penelitian dan pengabdian masyarakat khususnya ke internal organisasi. Proses ini sesuai dengan hasil perancangan kegiatan dengan laporan kegiatan sampai dengan penilaian serta umpan balik yang didapatkan. Proses ini mendukung identifikasi tugas dan umpan balik, 4) Pelaporan Kegiatan adalah proses melakukan pembuatan laporan yang dapat digunakan sebagai acuan kegiatan berbagi pengetahuan atau disimpan sebagai arsip untuk kepentingan administrasi program studi. Proses ini adalah dokumentasi dari semua kegiatan program studi dalam pengembangan pengetahuan. Proses pelaporan kegiatan akan mendukung umpan balik.

\section{Perancangan Model Sistem Informasi}

Perancangan model sistem informasi menggunakan Data Flow Diagram (DFD) untuk memodelkan proses-proses yang ada dalam knowledge sharing system di program studi Teknik Informatika. Diagram konteks mengacu pada proses-proses utama yang dilaksanakan dalam rancangan sistem informasi di lingkungan Program Studi Fakultas Teknik Universitas Pasundan, khususnya di Program Studi Teknik Informatika maka disusunlah struktur proses dari Sistem Informasi Knowledge Sharing Systems. Diagram konteks memperlihatkan eksternal 
entity dari Sistem Informasi Knowledge Sharing Systems yang terdiri dari Program Studi Teknik Informatika, Koordinator Program Studi, Dosen, Komunitas Keilmuan dan Sumber Pengetahuan. Setiap entitas eksternal berelasi dengan sistem informasi dalam memberi dan mendapatkan informasi dalam berbagi pengetahuan dimana salah satu tujuan utamnya adalah memberikan dosen informasi pengetahuan terbaru baik dari penelitian dosen lain, komunitas keilmuan atau sumber-sumber pengetahuan lain seperti hasil penelitian, pengabdian masyarakat, pengajaran dan lain-lain. Selanjutnya dosen dapat memberikan umpan balik dengan pengetahuan berupa penelitian yang telah dilaksanakan ke dalam sistem informasi.

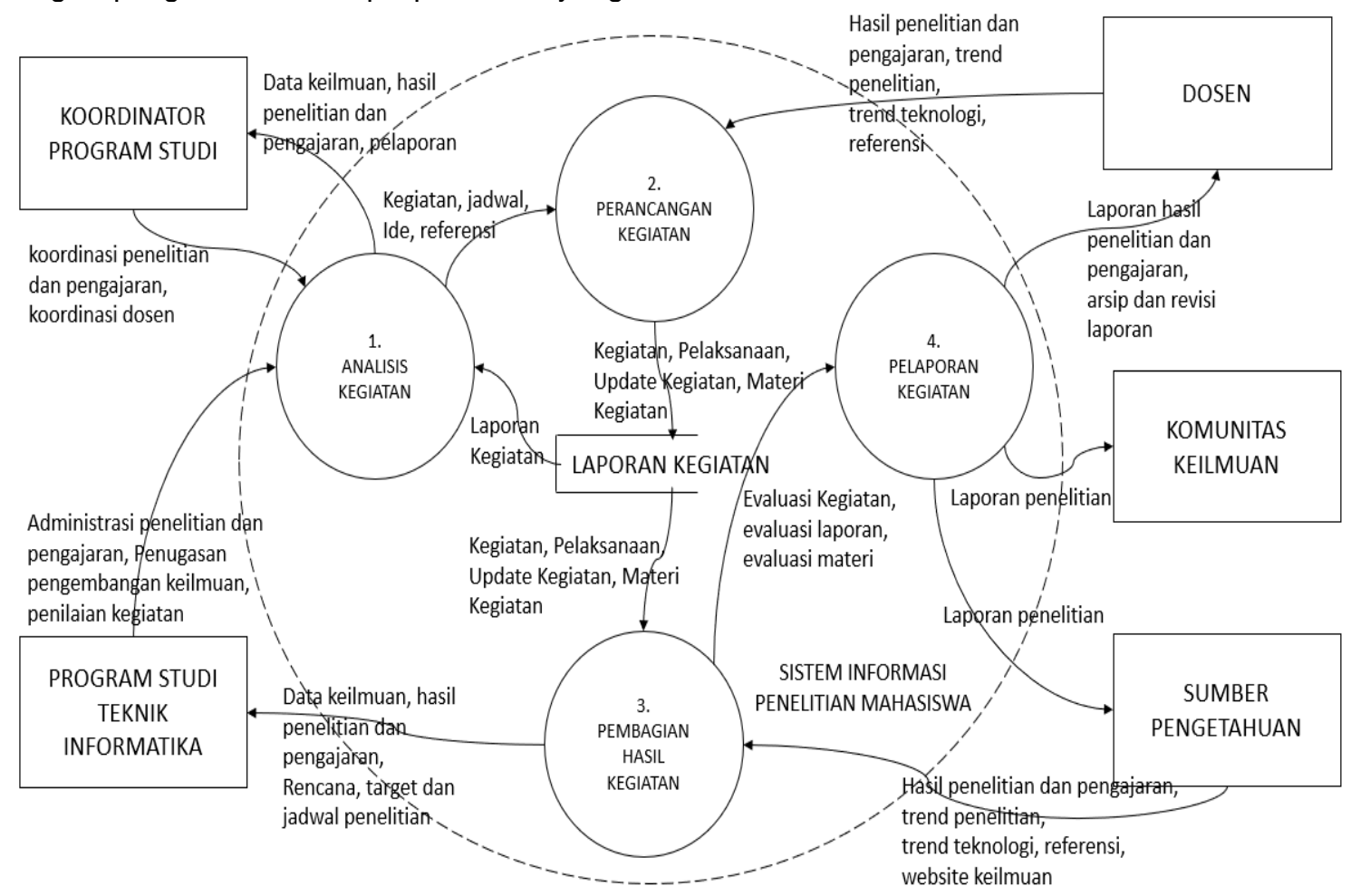

Sumber: Hasil Penelitian (2021)

Gambar 4. Data Flow Diagram Level 1 Sistem Informasi Knowledge Sharing Systems

\section{Model Mental Dan Model Proses}

Model mental digunakan orang ketika akan menggunakan suatu teknologi, untuk mencoba memahami apa yang harus dilakukan ketika hal yang tidak terduga terjadi atau ketika menghadapi produk yang tidak dikenal untuk pertama kalinya. Semakin banyak seseorang mempelajari suatu produk dan bagaimana fungsinya, semakin berkembang model mentalnya. Dalam psikologi kognitif, model mental telah didalilkan sebagai konstruksi internal dari beberapa aspek dunia luar yang dimanipulasi, memungkinkan prediksi dan kesimpulan dibuat. Proses ini dianggap melibatkan menyempurnakan dan menjalankan model mental. Pemahaman banyak orang tentang cara kerja teknologi dan layanan masih kurang baik sehingga model mental mereka seringkali tidak lengkap, membingungkan, dan didasarkan pada analogi dan kepercayaan yang tidak tepat. Akibatnya, mereka merasa sulit mengidentifikasi, mendeskripsikan, atau memecahkan masalah, dan mereka kekurangan kata-kata atau konsep untuk menjelaskan apa yang terjadi. Dalam penelitian ini model mental diterjemahkan menjadi proses mental yang lebih terstruktur prosesnya, mengacu pada model sistem informasi Knowledge Sharing Systems di Program Studi Teknik Informatika. Struktur proses beserta tempat penyimpanannya akan menjadi masukan untuk langkah-langkah proses yang merupakan dekomposisi proses utama menjadi beberapa proses yang lebih detail.

Tujuan dari struktur proses dan tahap atau langkah-langkah proses adalah untuk menangkap dan mengekstraksi pengetahuan dari setiap individual secara lebih terstruktur dan mudah. Dimana langkah-langkah proses ini akan menjadi masukan untuk aturan dalam sistem basis data untuk menentukan aksi yang akan dilakukan terhadap pengetahuan tertentu. Aktivitas manajemen pengetahuan merupakan kombinasi dari proses bisnis dan teknologi informasi. Sistem KM menggunakan proses bisnis, atau proses kerja, Database Management 
System (DBMS) sebagai sarana penyimpanan pengetahuan. Sebagian besar aktivitas manajemen pengetahuan saat ini bergantung pada database dan sistem internet, biasanya disimpan dalam database baik sebagai tabel sederhana atau teks semi-terstruktur.

\section{Knowledge Store}

Untuk mendapatkan kembali pengetahuan dengan cara terbaik dan teraman, sistem basis data yang dirancang harus memungkinkan membuat query (permintaan informasi ke basis data) secara selektif cepat dalam lingkungan yang terkontrol. Pengetahuan dipecah menjadi "fakta" atom permanen yang dapat disimpan dalam database relasional standar dan diproses dengan sangat efisien. DBMS akan menyediakan query yang efisien dari basis pengetahuan, inferensi efisien dari pengetahuan baru dan terjemahan ke dalam dan keluar dari bahasa alami. Beberapa organisasi memiliki proses sistematis untuk menangkap pengetahuan, yang berbeda dari prosedur penangkapan informasi konvensional. Berdasarkan premis ini, solusi dari dalam, yang mandiri, agar tidak bergantung pada sumber daya dari luar, menggunakan alat, yang tidak biasa bagi karyawan. Manajemen pengetahuan dapat disimpan dan dikelola oleh DBMS. Dalam melakukan pemetaan dari proses bisnis knowledge sharing system (KSS) ke dalam model basis data akan dilakukan dengan cara: 1) Daftarkan semua proses, yaitu: $P(A, 1)$ hingga $P(A, n), 2)$ Pertahankan dan pelihara sistem KSS, 3) Kembangkan $P(A, 1)$ menjadi $P(M, 1)$, 4) Uji $P(M, 1)$ dalam lingkungan kerja operasional, 5) Perbaiki dan modifikasi $P(M, 1) y a n g$ diperlukan dan validasi, 6) Gantikan $P(A, 1)$ dengan $P(M, 1), 7)$ Iterasi prosedur ke semua $P$ yang tersisa $(A, n), 8)$ Kembali ke nomor 1, jika semua proses telah semuanya dipetakan maka siklus selesai.

Selanjutnya didefinisikan apa saja fakta, langkah, aturan, tindakan, informasi terdokumentasi dan tidak terdokumentasi yang relevan dengan proses bisnis dalam penelitian ini. Mengumpulkan semua pengetahuan tacit yaitu segala sesuatu yang disampaikan di antara semua kegiatan dosen, tidak hanya ketika mereka bekerja secara resmi tetapi juga ketika mereka bertukar informasi dan pengalaman tentang kebiasaan pengajaran, penelitian dan pengabdian masyarakat. Proses mental diterjemahkan ke dalam bentuk terstruktur yang selanjutnya diubah menjadi langkah (steps), aturan (rules) dan tindakan (actions), seperti yang diilustrasikan pada gambar di atas. Ditulis sebagai berikut [4] :

PM $\rightarrow$ PS: \{Steps, (Rules), Actions\}

PM dan PS, adalah Proses Mental dan Struktur proses.

$\mathrm{PMi} \rightarrow \mathrm{PSi}:\{$ Step $(\mathrm{PMi})+($ Rules $(\mathrm{PMi}))+$ Actions $(\mathrm{PMi})\}$

Process $\mathrm{i}=($ Step $1+$ Step $2+\ldots$ Step $n)$

Stepi $=($ Rule1 + Rule2 $+\ldots \ldots \ldots .$. Rule $n)+($ Action1 + Action $2+. .+$ Action $n)$ maka

Process $\mathrm{i}=($ Step i ... Step $\mathrm{n})+($ Rule i ... Rule $\mathrm{n})+($ Action $\mathrm{i} . . .+$ Action $n)$ atau

Processi $=\sum$ (Step $\mathrm{i}$ to $\mathrm{n}$, (Rule $\mathrm{i}$ to $\left.\mathrm{n}\right)$, Action $\mathrm{i}$ to $\mathrm{n}$ )

\section{Konten Basis Data}

Model basis data berikut adalah konten yang disederhanakan untuk penelitian ini. Mendefinisikan proses yang terlibat dalam rancangan basis data, kemudian secara lebih rinci mendaftarkan proses. Perbedaan antara proses adalah jumlah langkah dan kompleksitasnya masing-masing, seperti yang diungkapkan oleh seperangkat aturan yang terlibat.

Tabel 1. Tabel Proses

\begin{tabular}{ll}
\hline Kode_Proses & Deskripsi Proses \\
\hline AK & Analisis Kegiatan \\
\hline PK1 & Perancangan Kegiatan \\
\hline PHK & Perancangan Hasil Kegiatan \\
\hline PK2 & Pelaporan Kegiatan \\
\hline
\end{tabular}

Sumber: Hasil Penelitian (2021)

Tabel Proses adalah tabel yang berisi proses bisnis utama, yang menjadi pemetaan dari model proses dalam pembagian pengetahuan di Program Studi, terdiri dari 4 proses utama yang merupakan siklus dalam sistem yang akan menjadi konten dari basis data.

Tabel 2. Tabel Langkah Proses

\begin{tabular}{lrll}
\hline Kode_Proses & Langkah & Deskripsi & Kode Form \\
\hline AK & 1 & Pencatatan lata belakang pendidikan & FRM1 \\
\hline AK & 2 & Review materi kegiatan & \\
\hline AK & 3 & Review pelaksanaan kegiatan & \\
\hline AK & 4 & Review penilaian kegiatan & \\
\hline
\end{tabular}




\begin{tabular}{lrll}
\hline Kode_Proses & Langkah & Deskripsi & Kode Form \\
\hline AK & 5 & Revisi target kegiatan & FRM2 \\
\hline AK & 6 & Revisi target kegiatan & FRM3 \\
\hline PK1 & 1 & Penentuan lingkup kegiatan & \\
\hline PK1 & 2 & Penentuan w aktu pelaksanaan kegiatan & \\
\hline PK1 & 3 & Penentuan pelaksana kegiatan & \\
\hline PK1 & 4 & Pelaksanaan lingkup kegiatan & FRM4 \\
\hline PK1 & 5 & Revisi lingkup kegiatan & FRM5 \\
\hline PK1 & 6 & Evaluasi kegiatan & \\
\hline PHK & 1 & Pembagian hasil kegiatan ilmiah & \\
\hline PHK & 2 & Pembagian hasil kegiatan penelitian & \\
\hline PHK & 3 & Pembagian hasil kegiatan pengabdian kepada masyarakat & \\
\hline PHK & 4 & Pencatatan media kegiatan & \\
\hline PHK & 5 & Pencatatan media umpan balik kegiatan & \\
\hline PK2 & 1 & Pembuatan laporan & FRM6 \\
\hline PK2 & 2 & Revisi laporan & \\
\hline PK2 & 3 & Pengarsipan & \\
\hline Sumber: Hasil Penelitian & $(2021)$ &
\end{tabular}

Tabel langkah proses adalah dekomposisi dari proses utama pembagian pengetahuan di Program Studi. Langkah proses mencerminkan proses yang lebih spesifik dalam pembagian pengetahuan termasuk pemanfaatan formulir untuk laporan dan arsip.

Tabel 3. Tabel Form

\begin{tabular}{ll}
\hline Kode_Proses & Deskripsi Proses \\
\hline FRM1 & Form Kegiatan Keilmuan \\
\hline FRM2 & Form Review Keilmuan \\
\hline FRM3 & Form Nilai Kegiatan Keilmuan \\
\hline FRM4 & Form Data Kegiatan \\
\hline FRM5 & Form Laporan Kegiatan \\
\hline FRM6 & Form Arsip Kegiatan \\
\hline Sumber: Hasil Penelitian (2021)
\end{tabular}

Sumber: Hasil Penelitian (2021)

Tabel form adalah semua formulir yang digunakan dalam sistem manajemen pengetahuan yang berfungsi masukan dari pengetahuan eksplisit setiap dosen dan menangkap, memformat dan mencatat pengetahuan tacit khususnya dalam kegiatan dan pembahasan (review) keilmuan di bidang informatika dan ilmu komputer.

\begin{tabular}{lll}
\multicolumn{3}{c}{ Tabel 4. Tabel Aksi } \\
\hline Kode_Aksi & Deskripsi & Pengawas \\
\hline A1 & Koordinasi penelitian, pengabdian masyarakat & Koordinator Penelitian \& PPM \\
\hline A2 & Koordinasi dosen dan pengajaran & Koordinator Pendidikan \& Pengajaran \\
\hline A3 & Koordinasi kuliah & Koordinator Dosen Mata Kuliah \\
\hline A4 & Penelitian dan pengajaran & Dosen \\
\hline A5 & Administrasi penelitian, pengajaran dan penilaian & Program Studi/Fakultas \\
\hline A6 & Publikasi dan pembagian penelitian & Koordinator Penelitian dan Dosen \\
\hline A7 & Koordinasi pembagian hasil penelitian dan pengajaran & Program Studi \\
\hline A8 & Review penelitian dan pengabdian masyarakat & Dosen Bidang Keilmuan \\
\hline
\end{tabular}

Sumber: Hasil Penelitian (2021)

Tabel aksi adalah tabel yang mendeskripsikan pihak-pihak yang terlibat dalam sistem pembagian pengetahuan di Program Studi. Pihak yang terlibat memiliki fungsi administrasi, pelaksanaan, validasi (administrasi \& keilmuan), pengawasan dan penilaian terhadap pengetahuan dalam kegiatan dosen di bidang pengajaran, penelitian dan pengabdian masyarakat.

Tabel 5. Tabel Aturan

\begin{tabular}{|c|c|c|c|c|c|c|c|c|c|c|}
\hline $\begin{array}{l}\text { Kode_- } \\
\text { Proses }\end{array}$ & Langkah & $\begin{array}{l}\text { Kode__ } \\
\text { Aturan }\end{array}$ & Deskripsi & Nilai & Unit & Keterangan & A-1 & A-2 & A-3 & A-4 \\
\hline AK & 1 & $\mathrm{R} 1$ & Pencatatan lengkap & 1 & semester & $\begin{array}{l}\text { Tidak ada } \\
\text { revisi }\end{array}$ & $\mathrm{A} 1$ & A2 & A4 & A5 \\
\hline$\overline{\mathrm{AK}}$ & 1 & $\mathrm{R} 2$ & $\begin{array}{l}\text { Pencatatan tidak } \\
\text { lengkap }\end{array}$ & & & $\begin{array}{l}\text { Input } \\
\text { berulang }\end{array}$ & $\mathrm{A} 1$ & A2 & A4 & A5 \\
\hline$\overline{A K}$ & 1 & R3 & Revisi pencatatan & & & Ada revisi & $\mathrm{A} 1$ & $\mathrm{~A} 2$ & A4 & A5 \\
\hline $\mathrm{AK}$ & 2 & R4 & $\begin{array}{l}\text { Pengajuan materi } \\
\text { kegiatan }\end{array}$ & 1 & semester & $\begin{array}{l}\text { Tidak ada } \\
\text { revisi }\end{array}$ & $\mathrm{A} 1$ & A4 & A5 & \\
\hline$\overline{A K}$ & 2 & R5 & $\begin{array}{l}\text { Perbaikan materi } \\
\text { kegiatan }\end{array}$ & & & $\begin{array}{l}\text { Input } \\
\text { berulang }\end{array}$ & $\mathrm{A} 1$ & A4 & A5 & \\
\hline$\overline{A K}$ & 2 & R6 & Penerimaan materi & & & Ada revisi & A1 & A4 & A5 & \\
\hline
\end{tabular}




\begin{tabular}{|c|c|c|c|c|c|c|c|c|c|c|}
\hline $\begin{array}{l}\text { Kode- } \\
\text { Proses } \\
\end{array}$ & Langkah & $\begin{array}{l}\text { Kode } \\
\text { Aturan }\end{array}$ & Deskripsi & Nilai & Unit & Keterangan & A-1 & A-2 & A-3 & A-4 \\
\hline & & & kegiatan & & & & & & & \\
\hline $\mathrm{AK}$ & 3 & $\mathrm{R} 7$ & Review diterima & 1 & semester & & $\mathrm{A} 1$ & A5 & A8 & \\
\hline $\mathrm{AK}$ & 3 & $\mathrm{R} 8$ & Review ditolak & & & & $\mathrm{A} 1$ & A5 & A8 & \\
\hline $\mathrm{AK}$ & 4 & $\mathrm{R} 9$ & $\begin{array}{l}\text { Hasil penilaian } \\
\text { kemajuan kegiatan }\end{array}$ & & & & A5 & A8 & & \\
\hline $\mathrm{AK}$ & 5 & $\mathrm{R} 10$ & Target kegiatan & & & & A5 & A8 & & \\
\hline AK & 6 & $\mathrm{R} 11$ & $\begin{array}{l}\text { Hasil penilaian } \\
\text { akhir }\end{array}$ & & & & A5 & A8 & & \\
\hline PK1 & 1 & $\mathrm{R} 12$ & Lingkup kegiatan & & & & A4 & A8 & & \\
\hline PK1 & 2 & R13 & $\begin{array}{l}\text { Waktu pelaksanaan } \\
\text { kegiatan }\end{array}$ & 1 & semester & & $\bar{A} 4$ & A5 & & \\
\hline PK1 & 2 & R14 & $\begin{array}{l}\text { Revisi w aktu } \\
\text { pelaksanaan } \\
\text { kegiatan }\end{array}$ & & & $\begin{array}{l}\text { Berlanjut ke } \\
\text { semester } \\
\text { berikut }\end{array}$ & $\overline{\mathrm{A} 4}$ & A5 & & \\
\hline PK1 & 3 & R15 & Pelaksana kegiatan & & & & A4 & A5 & & \\
\hline PK1 & 3 & R16 & $\begin{array}{l}\text { Tambah/kurang } \\
\text { pelaksana kegiatan }\end{array}$ & & & & A4 & A5 & & \\
\hline PK1 & 4 & R17 & Lingkup kegiatan & 1 & semester & $\begin{array}{l}\text { Berlanjut ke } \\
\text { semester } \\
\text { berikut }\end{array}$ & A4 & A5 & & \\
\hline PK1 & 5 & R18 & $\begin{array}{l}\text { Revisi lingkup } \\
\text { kegiatan }\end{array}$ & & & & A4 & A5 & & \\
\hline PK1 & 6 & R19 & Evaluasi kegiatan & & & $\begin{array}{l}\text { Evaluasi } \\
\text { antara/akhir } \\
\text { kegiatan }\end{array}$ & $\mathrm{A} 1$ & A4 & A5 & \\
\hline $\mathrm{PHK}$ & 1 & $\mathrm{R} 20$ & $\begin{array}{l}\text { Hasil kegiatan } \\
\text { kuliah }\end{array}$ & 1 & semester & $\begin{array}{l}\text { Aw al/tengah/ } \\
\text { akhir } \\
\text { semester }\end{array}$ & $\mathrm{A} 2$ & A3 & A4 & A7 \\
\hline $\mathrm{PHK}$ & 2 & $\mathrm{R} 21$ & $\begin{array}{l}\text { Hasil kegiatan } \\
\text { penelitian }\end{array}$ & & & & $\mathrm{A} 2$ & A3 & A4 & A7 \\
\hline $\mathrm{PHK}$ & 3 & $\mathrm{R} 22$ & $\begin{array}{l}\text { Hasil kegiatan } \\
\text { pengabdian } \\
\text { masyarakat }\end{array}$ & & & & A2 & A3 & A4 & A7 \\
\hline PHK & 4 & $\mathrm{R} 23$ & Media kegiatan & & & & $\mathrm{A} 2$ & A3 & A4 & A7 \\
\hline PHK & 5 & R24 & $\begin{array}{l}\text { Umpan balik } \\
\text { kegiatan }\end{array}$ & & & & $\mathrm{A} 2$ & A3 & A4 & A7 \\
\hline PK2 & 1 & R25 & Laporan & & & & A4 & A5 & A6 & A8 \\
\hline PK2 & 2 & R26 & Laporan & & & & A4 & A5 & A6 & A8 \\
\hline PK2 & 3 & R27 & Arsip & & & & A4 & A5 & $\mathrm{A} 6$ & A8 \\
\hline
\end{tabular}

Sumber: Hasil Penelitian (2021)

Tabel Aturan adalah kombinasi dari Tabel Langkah Proses dan Tabel Aksi untuk menentukan proses yang akan atau sedang atau sudah selesai dilaksanakan yang mengacu pada nilai dan unit. Pihak-pihak yang secara spesifik terlibat dalam pelaksanaan proses mulai dari awal administrasi sampai dengan pengarsipan pengetahuan yang sudah dibagikan. Dalam penelitian ini hanya menggunakan 4 macam aturan (A-1, A-2, A-3 dan A-4) karena sesuai dengan kompleksitas bisnis proses sudah dianggap cukup, ini bisa terlihat dari baris Tabel Aturan tidak semuanya terisi oleh kode dari tabel Aksi. Dalam tabel ini terlihat bahwa pihak dosen (A4) dan pihak dosen yang tergabung dalam dosen bidang keilmuan (A8) terlibat hampir disemua proses dalam knowledge sharing system, yang untuk selanjutnya semua tabel yang ada akan dipetakan ke dalam sistem basis data.

\section{Entity Relationship Diagram}

Entity Relationship Diagram (ERD) dirancang sebagai dasar dalam pembangunan aplikasi basis data yang akan dipetakan menjadi basis data logik dan fisik setelah melewati proses normalisasi. Proses normalisasi adalah dekomposisi dari basis data fisik untuk meminimalisir pengulangan data atau redundansi serta anomali data dalam pencarian informasi (database query). Proses normalisasi dilakukan dengan memperhatikan kolom basis data yang mengalami pengulangan dan ketergantungan fungsional antar atribut (field) dalam sebuah tabel. ERD yang dirancang mengacu pada tabel-tabel yang telah dibuat pada bagian sebelumnya, memberikan relasi antar tabel serta membuat aturan kardinalitas dalam relasi antar tabel tersebut. 
Tahapan selanjutnya adalah pemetaan ke basis data fisik dengan melakukan normalisasi terhadap tabel aturan, dimana terdapat pengulangan pada atribut kode aksi. Normalisasi dilakukan dengan melakukan dekomposisi tabel dan membentuk tabel baru dengan nama Tabel Aksi Aturan, dengan kardinalitas banyak ke banyak sehingga relasi akan dijadikan sebagai tabel juga. Dari basis data yang telah dirancang maka informasi yang disimpan, khususnya mengenai proses, langkah proses, aksi yang mengacu pada aturan sehingga bisa dibuatkan laporan atau formulir dapat diakses, disebarkan dan dibagikan ke dosen pengajar. Setiap proses bukan hanya dapat menyimpan pengetahuan eksplisit selama pengajaran, penelitian dan pengabdian masyarakat tetapi juga pengetahuan tacit yang terjadi dalam komunikasi keilmuan antar dosen.

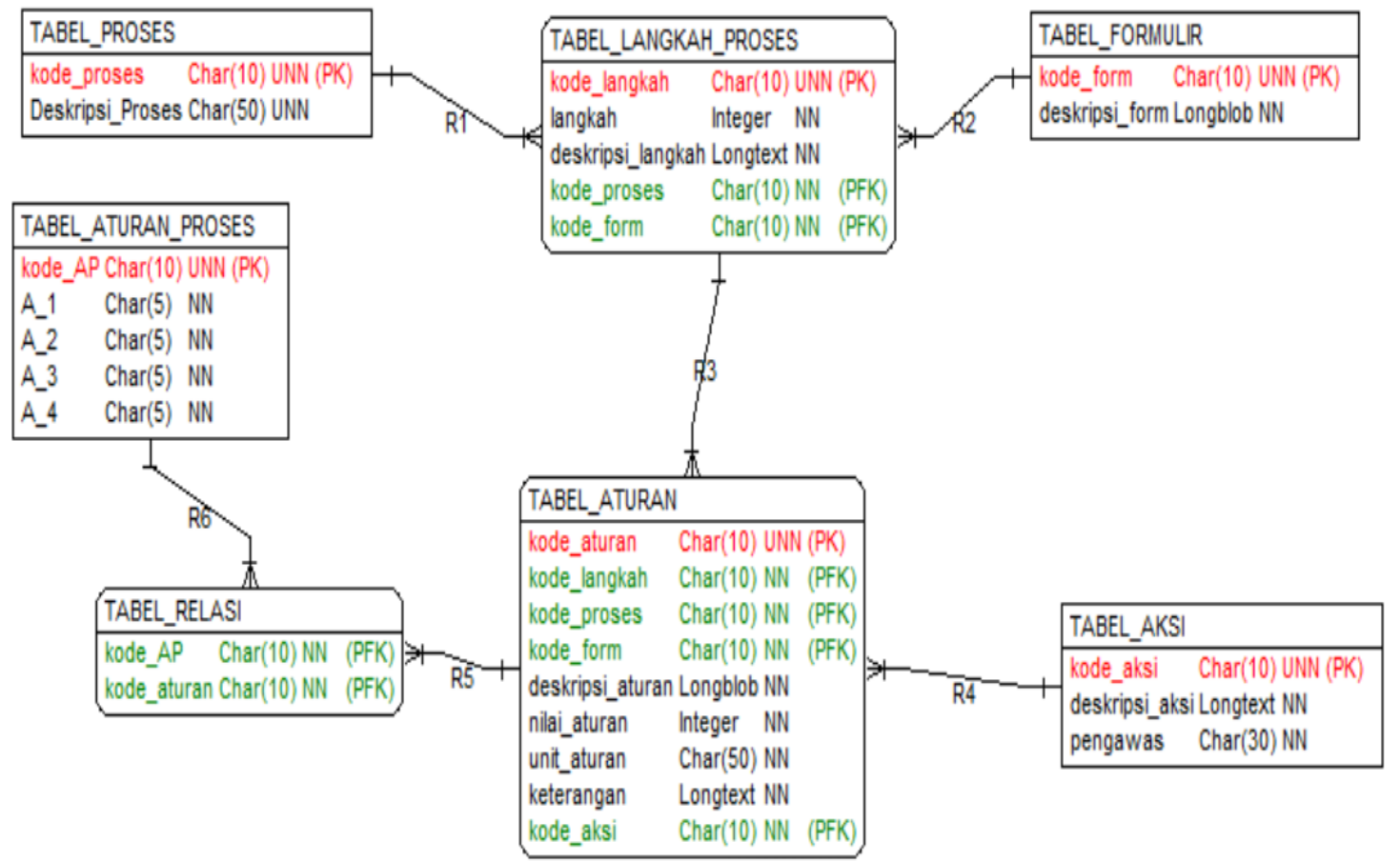

Sumber: Hasil Penelitian (2021)

Gambar 5. Basis Data Fisik KSSDB

\section{Kesimpulan}

Pendekatan penelitian menggunakan Knowledge Management Systems, dalam fokus penelitian ini adalah Knowledge Sharing Systems, tidak bisa lepas dari faktor manajemen dalam sebuah organisasi. Pengelolaan ini khususnya adalah manajemen personal dari pelaku dalam organisasi yang akan menjadi sumber pengetahuan dan yang mendapat keuntungan dari berbagi pengetahuan. Teori yang mendukung berbagi pengetahuan digunakan untuk merancang proses-proses dalam sistem informasi yang akan mendukung identifikasi tugas, otonomi dan umpan balik yang akan mendukung motivasi pelaku (dosen) dalam berbagi pengetahuan. Pemetaan yang menggunakan model manajemen pengetahuan akan mengidentifikasi tabel dan item data yang dapat digunakan untuk merancang sistem basis data. Penelitian ini dapat dilanjutkan dengan melakukan analisis yang lebih mendalam terhadap model konseptual Knowledge Sharing Systems di Program Studi Teknik Informatika dengan menurunkan proses bisnis ke sistem basis data. Identifikasi terhadap proses yang memerlukan perbaikan dalam pembagian pengetahuan akan menjadi sumber analisis lanjutan dan perancangan sistem informasi sampai dengan pembangunan sistem basis data yang dapat memanfaatkan teknologi internet untuk mendukung kemudahan pembagian pengetahuan.

\section{Ucapan Terima Kasih (Opsional)}

Peneliti mengucapkan banyak terimakasih kepada Fakultas Tekinik dan Program Studi Teknik Informatika Universitas Pasundan, Ketua Program Studi, para dosen dan pihak lain yang telah mendukung berjalannya kegiatan penelitian ini. 


\section{Referensi}

[1] Association for Computing Machinery (ACM) \& Association for Information Systems (AIS), "Curriculum Guidelines for Undergraduate Degree Programs in Information Systems," 2010.

[2] C. Coronel, S. Morris, "Database Systems: Design, Implementation, and Management", 11th Edition, Cengage Learning, 2015.

[3] C. E. Supriana, "Perancangan Knowledge Sharing Systems di Program Studi Teknik Informatika," Hibah Penelitian Fakultas Teknik Universitas Pasundan, 2019.

[4] E. Segev, "Mapping Knowledge Into A Database Model," Journal of Knowledge Management Practice, vol. 11, no. 1, 2010.

[5] I. Becerra-Fernandez, R. Sabherwal, "Knowledge Management Systems and Processes," Second Edition, Routledge, 2015

[6] J. Hoffer, R. Venkataraman, H. Topi, "Modern Database Management," 12th Edition, Pearson, 2016.

[7] L. G. Pee, A. Kankanhalli, H. W. Kim, "Knowledge Sharing in Information Systems Development: A Social Interdependence Perspective," Journal of the Association for Information Systems, 11, pp. 550-575, 2010.

[8] N.J. Foss, D. B. Minbaeva, T. Pedersen, M. Reinholt, "Encouraging Knowledge Sharing Among Employees: How Job Design Matters," Human Resource Management, Vol. 48, No. 6, Pp. 871- 893, 2009.

[9] R. K. Rainer Jr., B. Prince, C. Cegielski, "Introduction to Information Systems Supporting and Transforming Business," Fifth Edition, Wiley, 2014.

[10] S. S. Janus, Becoming A Knowledge-Sharing Organization: A Handbook for Scaling Up Solutions through Knowledge Capturing and Sharing," Word Bank Group, 2016.

[11] S. Wang, R. A. Noe, "Knowledge sharing: A review and directions for future research," Human Resource Management Review 20 pp. 115-131, 2010.

[12] W. R. King, (edt.), "Knowledge Management and Organizational Learning," Springer, 2009. 